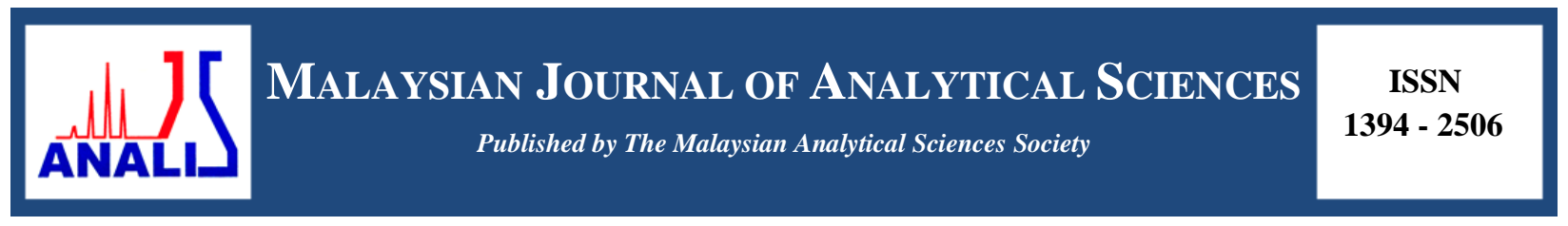

\title{
PREPARATION AND PHYSICOCHEMICAL PROPERTIES OF OCTENYL SUCCINIC ANHYDRIDE (OSA) MODIFIED SAGO STARCH
}

\section{(Penyediaan dan Sifat Fizikokimia Oktenil Suksinat Anhidrat (OSA) Modifikasi Kanji Sagu)}

\author{
Nur Farhana Zainal Abiddin, Anida Yusoff*, Noorlaila Ahmad \\ Department of Food Science and Technology, \\ Faculty of Applied Sciences, \\ Universiti Teknologi MARA, 40450 Shah Alam, Selangor, Malaysia \\ *Corresponding author: anida@salam.uitm.edu.my
}

Received: 24 February 2015; Accepted: 27 October 2015

\begin{abstract}
Starch from sago (Metroxylon sagu) was esterified with octenyl succinic anhydride (OSA) in order to regulate its shortcoming by adding amphiphilic properties. The objective of this work is to determine the physicochemical properties of native sago and OSA sago starches. The OSA sago starch was produced according to the optimum condition generated via response surface methodology (RSM) with $5.00 \%$ OSA at pH 7.20 and a reaction time of 9.65 hours. The esterified sago starch gives a degree of substitution (DS) value of 0.012 . The physicochemical properties of OSA sago starch was determined by measuring the amylose content, laser diffraction particle size analyzer, scanning electron microscopy (SEM) and Fourier transform infrared (FT-IR). The amylose content for OSA sago starch was found to be reduced after esterification reaction. The particle size of OSA sago starch was found to increase significantly $(p<0.05)$ compared to their native starches. Scanning electron microscopy (SEM) revealed that OSA starch developed slightly rough surface and their edges lost some definition. FT-IR spectroscopy shows that there was appearance of new absorption correspond to ester carbonyl group $\left(1717 \mathrm{~cm}^{-1}\right)$ and carboxylate RCOO- $\left(1569 \mathrm{~cm}^{-1}\right)$. This study showed that the physicochemical properties of modified starches were influenced not only by DS but also on the botanical origin of the starches.
\end{abstract}

Keywords: physicochemical properties, sago starch, octenyl succinic anhydride, esterification

\section{Abstrak}

Kanji daripada sagu (Metroxylon sagu) telah diesterifikasi dengan oktenil suksinat anhidrat (OSA) sebagai usaha untuk mengawal kelemahan dengan menambah sifat amfifilik. Objektif kajian ini adalah untuk menentukan sifat - sifat fizikokimia kanji sagu asli dan OSA kanji sagu. OSA kanji sagu disediakan mengikut keadaan optima berdasarkan kaedah gerak balas permukaan (RSM) dengan 5.00\% OSA pada pH 7.20 dan masa tindak balas selama 9.65 jam. Esterifikasi kanji sagu memberikan nilai darjah pengantian (DS) sebanyak 0.012. Ciri - ciri fizikokimia OSA kanji sagu ditentukan dengan mengira kandungan amilosa, saiz partikel laser pembelauan analisis, mikroskop imbasan elektron (SEM) dan Fourier transformasi inframerah (FT-IR). Kandungan amilosa untuk OSA kanji sagu didapati berkurangan selepas tindak balas esterifikasi. Saiz partikel OSA kanji sagu didapati meningkat dengan ketara $(p<0.05)$ berbanding saiz kanji sagu asli. Mikroskop imbasan elektron (SEM) menunjukkan bahawa OSA kanji sagu menghasilkan permukaan sedikit kasar dan kehilangan beberapa sisi definisi. FT-IR spektroskopi menunjukkan bahawa terdapat kemunculan penyerapan baru yang bersesuaian dengan kumpulan ester karbonil $\left(1717 \mathrm{~cm}^{-1}\right)$ dan RCOO- karboksilik $\left(1569 \mathrm{~cm}^{-1}\right)$. Kajian ini menunjukkan bahawa ciri - ciri fizikokimia kanji diubahsuai bukan hanya dipengaruhi oleh DS tetapi juga berdasarkan pada asal usul botanikal kanji tersebut.

Kata kunci: sifat-sifat fizikokimia, kanji sagu, oktenil suksinat anhidrat, esterifikasi 


\section{Nur Farhana et al: PREPARATION AND PHYSICOCHEMICAL PROPERTIES OF OCTENYL SUCCINIC ANHYDRIDE (OSA) MODIFIED SAGO STARCH}

\section{Introduction}

Starch is a carbohydrate polymer which comprised of amylose and amylopectin chains and has been widely used as a functional ingredient in food and non-food application [1]. In order to meet specific requirements, the native starches were chemically modified to improve its properties which require disruption of hydrogen bonding [2]. Chemical modification can be achieved by different types such as esterification, etherification, cross-linking and grafting of starch. Sago starch, like other starch, exhibit hydrophilic nature which is the main constraint that limit the usability of starch. Esterification of starch with octenyl succinic anhydride (OSA) impart an amphiphilic nature by the addition of hydrophobic chain into the starch backbone and broaden their potential uses in the food industry [3]. The succinylated starch tends to swell in cold water, having more stable pasting and gelatinisation properties also giving the derivative surface activity and colloid protector properties [4].

There are a number of methods that can be used to characterize starch, which could be used to identify the unique properties of modified starch. Scanning electron microscopy (SEM) has been used to study the morphology of the starch granules by giving a clear visual variation in size and shape of starch granule [5]. Laser diffraction particle size analyzer has been used to study the particle size by characterize the granule diameter, as the size of starch can influence the rate and efficiency of the chemical modification [6]. The presence of carbonyl group in the starch backbone can be confirmed by FT-IR spectroscopy. The introduction of this group indicate that the succinylation have been successfully made into the starch [7]. The amylose content of starch before and after modification can be as one of the sign to recognize the extent of modification by determining the degree of substitution. Amylose content also has been found to have a significant correlation with the size and shape of the starch granules [8].

Thus, the objective of the present study was to characterize the physicochemical properties of both native and OSA sago starch using different type of instruments.

\section{Chemicals and raw materials}

\section{Materials and Methods}

Food grade sago starch was purchased from Nee See Ngeng \& Sons Sago Industries Sdn. Bhd (Sarawak, Malaysia). The starch was used without any further treatment. Octenyl succinic anhydride (OSA) (Lot\# J1097009-A) was donated by Dixie Chemical Company, Pasadena, Texas, USA. Other chemicals used in this study were of analytical grade.

\section{Preparation of OSA starches}

OSA sago starch was prepared according to the optimum condition generated by response surface methodology (RSM). The starch was treated according to condition at 5.00\% OSA concentration, $\mathrm{pH} 7.20$ and reaction time of 9.65 hours as reported in our earlier work [9]. The preparation step and calculation of degree of substitution (DS) of OSA sago starch was determined using the method from [10] by using the formula equation 1 and 2 below:

$$
\operatorname{OSA} \text { substitution }(\%)=\frac{\left(V_{\text {blank }}-V_{\text {sample }}\right) \times 0.1 \times N \times 100}{W}
$$

where $V_{\text {blank }}$ is defined as the volume of $\mathrm{HCl}$ required for blank titration, $V_{\text {sample }}$ is defined as volume of $\mathrm{HCl}$ required to titrate the sample, $W$ is defined as the weight (g) of sample and $N$ is the normality of the $\mathrm{HCl}$ solution.

$$
\mathrm{DS}=\frac{162 \times \text { OSA substitution }(\%)}{21000-[209 \times \text { OSA substitution }(\%)]}
$$

where 162 is defined as molecular weight of the glucose unit, 21000 is defined as $100 \mathrm{x}$ molecular weight of octenyl succinyl group and 209 is molecular weight of octenyl succinyl group minus the molecular weight of hydrogen atom. 


\section{Characterization of OSA starches: Amylose content}

The amylose content of starches was estimated following the modification by Ratnayake et al. [11] from the method of McGrance et al. [12]. Starch (20 mg, dry basis) was dissolved in $8 \mathrm{~mL}$ of $90 \%$ DMSO. The slurry was vigorously mixed for $20 \mathrm{~min}$ and volume to $25 \mathrm{~mL}$ in a volumetric flask. The diluted solution $(1 \mathrm{~mL})$ was taken out and mixed with deionized water then placed in water bath at $85^{\circ} \mathrm{C}$ for $15 \mathrm{~min}$. The vials were left to cool at ambient temperature before make up the volume to $25 \mathrm{~mL}$ in a volumetric flask. The diluted solution $(1 \mathrm{~mL})$ was taken out and mixed with deionized water $(40 \mathrm{~mL})$ and iodine solution $(5 \mathrm{~mL})$. The volume of the mixture was adjusted to a final value of $50 \mathrm{~mL}$. Then, the solution was allowed to stand for at least $15 \mathrm{~min}$ and the absorbance was read at 600 $\mathrm{nm}$ by using UV-VIS spectrophotometer. A standard curve of amylose was plotted in order to determine the amylose content of native and OSA starches.

\section{Particle size of starch}

Particles size of OSA sago starch was measured by static multi-angle light scattering method using Mastersizer Hydro 2000 (Malvern Instrument, Malvern, UK) equipped with Scirocco Dry Powder Feeder. An amount $2 \mathrm{~g}$ of native and OSA starches were added into the feeder and the OSA sago starch was measured three times. An average droplet sizes were characterized in terms of Sauter mean diameter $\mathrm{d}_{32}$.

\section{Scanning electron microscopy}

The microstructure of starch granule and their surfaces after modification with OSA was examined with scanning electron microscopy (SEM). The air-dried starch powders were stuck on double-sided adhesive tape on a specimen holder and then coated with gold in vacuum evaporator. The samples were analyzed using scanning electron microscope (Leo Supra 50VP Field Emission SEM, Carl Zeiss SMT, Germany). The samples were measured at a magnification of 2000x.

\section{Fourier transfer infrared (FT-IR) spectroscopy}

FT-IR spectra of native and OSA starches were performed using Perkin Elmer Spectrum One FT-IR spectrophotometer (Massachusetts, USA). The starch samples were dried at $105{ }^{\circ} \mathrm{C}$ for 12 hours to remove any moisture. The dried sample was finely grind with $\mathrm{KBr}$ in a ratio of $1: 70(\mathrm{w} / \mathrm{w})$ and scanned over a wavenumber range from 400 to $4000 \mathrm{~cm}^{-1}$ with a resolution of $4 \mathrm{~cm}^{-1}$.

\section{Statistical analysis}

All tests were performed in triplicate. Analysis of variance (ANOVA) was performed using the Duncan multiple range tests to compare treatments means. Significance was defined at $p<0.05$.

\section{Amylose content for native and OSA starches}

\section{Results and Discussion}

Table 1 shows the amylose content for native and modified starches after being esterified with OSA. Normally, botanical origin will influence the amount of amylose in the starch where waxy starches contain less than $15 \%$ amylose, regular starch $20-35 \%$ amylose and high amylose starch have more than $40 \%$ amylose [13]. The amylose content of native sago starch and OSA sago starch were $30.18 \%$ and $25.27 \%$, respectively. This result was supported by Ahmad et al. [14] which reported that the amylose content of native sago starch was in the range of 24 $-30 \%$. According to the amylose content, sago starch can be categorized as a regular starch.

From the result, there was a significant $(p<0.05)$ decrease in amylose content in treated starch. Amylose is located at the amorphous region while amylopectin is in crystalline lamellae. The amorphous region is more accessible than crystalline domains which explain that substitution occur preferentially at amylose chains [15]. As amorphous region is easily accessible, OS group might distribute and disrupt at this region more than in crystalline domains, which explain the reduction of amylose content in esterified starches [16].

\section{Particle size distribution and morphology of starches}

The results for particle size analysis are shown in Table 1. The particle size of native sago starch was $29.05 \mu \mathrm{m}$. This agreed with the result from [17] which state that the particle size of native sago granules was between 5 to 65 $\mu \mathrm{m}$ and the average was $30-31 \mu \mathrm{m}$. The particle size of esterified starch shows a significant increased $(p<0.05)$ 
when compared to their native state. Structural disorder happens as OS groups incorporate with native starch, making the granule to swell to a greater extent and increase the particle size [18].

Table 1. Effect of octenyl succinylation on DS, amylose content and particle size of starches

\begin{tabular}{cccc}
\hline Sample & $\begin{array}{c}\text { Degree of substitution } \\
(\mathbf{D S})\end{array}$ & $\begin{array}{c}\text { Amylose content } \\
(\boldsymbol{\%})\end{array}$ & $\begin{array}{c}\text { Particle size } \\
(\boldsymbol{\mu m})\end{array}$ \\
\hline Native sago starch & - & $30.18 \pm 0.71^{\mathrm{a}}$ & $29.05 \pm 0.09^{\mathrm{b}}$ \\
OSA sago starch & $0.012 \pm 0.00$ & $25.27 \pm 0.36^{\mathrm{b}}$ & $29.89 \pm 0.23^{\mathrm{a}}$ \\
\hline \multicolumn{2}{l}{$\begin{array}{l}\text { Values are mean } \pm \text { standard deviation. Mean within each column with different superscripts letter are } \\
\text { significantly different at } p<0.05 .\end{array}$}
\end{tabular}

Figure 1 shows the SEM image of native and OSA sago starch. Scanning electron microscopy revealed sago starch consists of oval granules with smooth surfaces and non-visible pores $[14,19]$. There is an only slight difference in shape of OSA sago starch from their original shape. However, the surface of OSA starch was observed to be rough and their edges lose some definition. The addition of $\mathrm{NaOH}$ to maintain the alkaline condition during esterification process might result in surface gelatinization, thus contribute to rough appearance on the surface of OSA starch granules [6]. This observation also could be associated with granule swelling and distruption of starch particles during reaction [20].

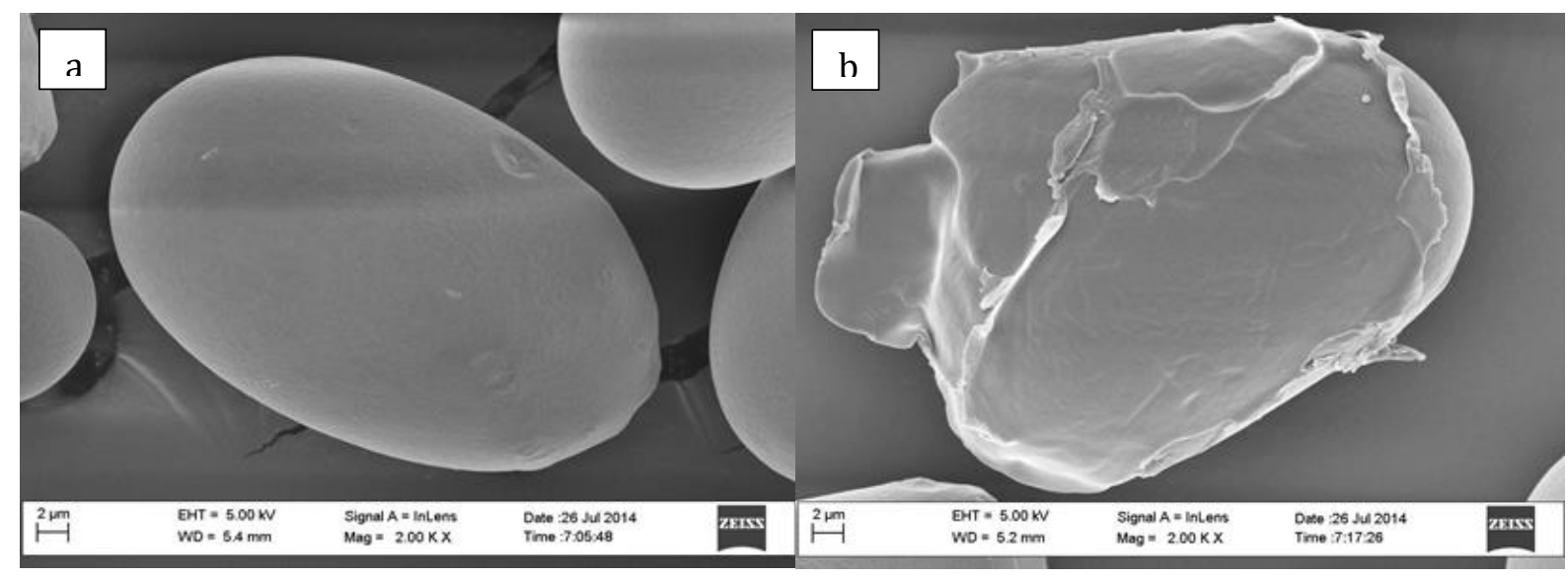

Figure 1. Scanning electron micrographs of a) native sago starch and b) OSA sago starch at 2000x magnification

\section{Fourier transfer infrared (FT-IR) spectroscopy}

Fourier transform infrared spectroscopy (FT-IR) was used to detect the presence of OSA groups after esterification. The FT-IR spectra of native and OSA starches are shown in Figure 2. The extremely broad band at $3400 \mathrm{~cm}^{-1}$ is resulting from vibration of hydroxyl group $(\mathrm{O}-\mathrm{H})$ whereas the band at $2924 \mathrm{~cm}^{-1}$ is characteristics of $\mathrm{C}-\mathrm{H}$ stretching vibration of glucose unit. Compared with native starch, two absorption bands were observed at $1569 \mathrm{~cm}^{-1}$ and 1717 $\mathrm{cm}^{-1}$ which correspond to assymetric stretch of vibration of a carboxyl group and $\mathrm{C}=\mathrm{O}$ stretching vibration of an ester group, respectively [21]. The peak at $1647 \mathrm{~cm}^{-1}$ was due to tightly bound water present in the starch [22]. The intensity of absorption bands at $1569 \mathrm{~cm}^{-1}$ and $1717 \mathrm{~cm}^{-1}$ was reported to increase with increasing DS [23]. 


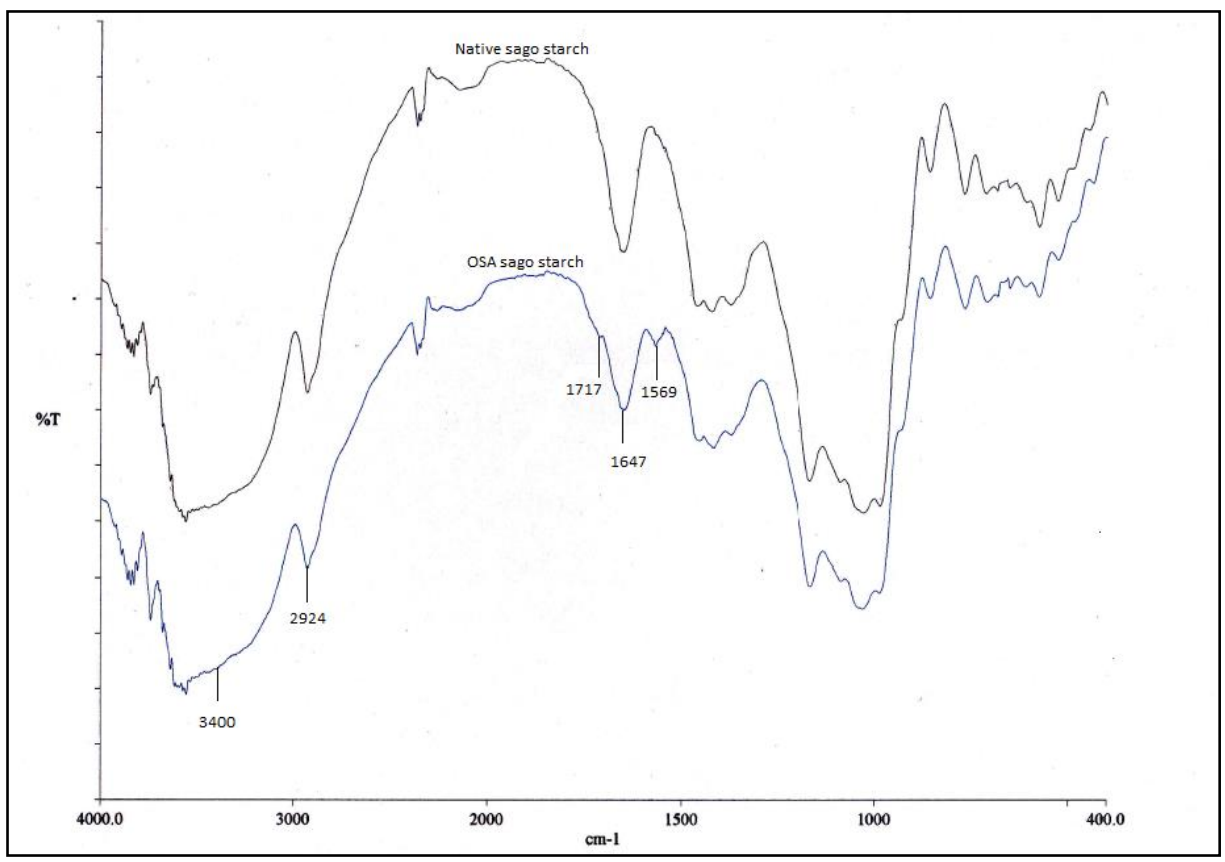

Figure 2. FT-IR spectra for native and OSA sago starches

\section{Conclusion}

Our results have shown that the physicochemical properties of native sago starch have been altered after being esterified with OSA. SEM image illustrated that there is only a slight change in the surface of the esterified starch, but does not bring any visible pores or crack on the starch surfaces. Particle size of starch granules was found to increase significantly $(p<0.05)$, which correspond to swelling activity. The amylose content of starch decreased after esterification, indicating that the modification occurred primarily in the amorphous regions and disrupt the linearity of amylose chains. FT-IR spectroscopy confirmed the existence of carbonyl group through absorption bands at $1569 \mathrm{~cm}^{-1}$ and $1717 \mathrm{~cm}^{-1}$. The esterification of sago starch with OSA will add the hydrophobic chain to the originally hydrophilic starch molecule hence the modified starch obtains surface active properties which will be useful in stabilizing emulsion. The stabilizing and emulsifying properties of OSA sago starch need further study.

\section{Acknowledgement}

The authors would like to thank Universiti Teknologi MARA (600-RMI/ERGS 5/3 (2/2013)) and Ministry of Higher Education Malaysia for the facilities and financial support.

\section{References}

1. Steeneken, P. A. M. and Woortman, A. J. J. (2008). Surface effects in the acetylation of granular potato starch. Carbohydrate Research, 343(13): 2278 - 2284.

2. Chang, P. R., Qian, D., Anderson, D. P. and Ma, X. (2012). Preparation and properties of the succinic ester of porous starch. Carbohydrate Polymers, 88: $604-608$.

3. Segura-Campos, M., Chel-Guerrero, L. and Betancur-Ancona, D. (2010). Effects of octenylsuccinylation on functional properties of lima bean (Phaseolus Lunatus) starch. Journal of Food Process Engineering, 33(4): $712-727$.

4. Segura-Campos, M., Chel-Guerrero, L. and Betancur-Ancona, D. (2008). Synthesis and partial characterization of octenylsuccinic starch from Phaseolus Lunatus. Food Hydrocolloids, 22(8): 1467 - 1474.

5. Singh, N., Singh, J., Kaur, L., Sodhi, N. S. and Gill, B. S. (2003). Morphological, thermal and rheological properties of starches from different botanical sources. Food Chemistry, 81(2): 219 - 231. 
6. Singh, J., Kaur, L. and McCarthy, O. J. (2007). Factors influencing the physico-chemical, morphological, thermal and rheological properties of some chemically modified starches for food applications - A review. Food Hydrocolloids, 21(1): 1 - 22.

7. Wang, J., Su, L. and Wang, S. (2010). Physicochemical properties of octenyl succinic anhydride-modified potato starch with different degrees of substitution. Journal of the Science of Food and Agriculture, 90(3): 424 $-429$.

8. Kaur, L., Singh, N. and Sodhi, N. S. (2002). Some properties of potatoes and their starches II. Morphological, thermal and rheological properties of starches. Food Chemistry, 79(2): 183 - 192.

9. Zainal Abiddin, N. F., Yusoff, A. and Ahmad, N. (2015). Optimisation of reaction conditions of octenyl succinic anhydride (OSA) modified sago starch using response surface methodology (RSM). International Food Research Journal, 22(3): 930 - 935.

10. Bhosale, R. and Singhal, R. (2006). Process optimization for the synthesis of octenyl succinyl derivative of waxy corn and amaranth starches. Carbohydrate Polymers, 66(4): $521-527$.

11. Ratnayake, W. S., Hoover, R., Shahidi, F., Perera, C. and Jane, J. (2001). Composition, molecular structure, and physicochemical properties of starches from four field pea (Pisum sativum L.) cultivars. Food Chemistry, 74(2): $189-202$.

12. McGrance, S. J., Cornell, H. J. and Rix, C. J. (1998). A simple and rapid colorimetric method for the determination of amylose in starch products. Starch-Stärke, 50(4): $158-163$.

13. Tester, R. F., Karkalas, J. and Qi, X. (2004). Starch-composition, fine structure and architecture. Journal of Cereal Science, 39(2): $151-165$.

14. Ahmad, F. B., Williams, P. A., Doublier, J-L., Durand, S. and Buleon, A. (1999). Physico-chemical characterisation of sago starch. Carbohydrate Polymers, 38(4): $361-370$.

15. van der Burgt, Y. E. M., Bergsma, J., Bleeker, I. P., Mijland, P. J. H. C., van der Kerk-van Hoof, A., Kamerling, J. P. and Vliegenthart, J. F. G. (2000). Distribution of methyl substituents im amylose and amylopectin from methylated potato starches. Carbohydrate Research, 325(3): $183-191$.

16. Nor Nadiha, M. Z., Fazilah, A., Bhat, R. and Karim, A. A. (2010). Comparative susceptibilities of sago, potato and corn starches to alkali treatment. Food Chemistry, 121(4): 1053 - 1059.

17. Kaur, B., Fazilah, A. and Karim, A. A. (2011). Alcoholic-alkaline treatment of sago starch and its effect on physicochemical properties. Food and Bioproducts Processing, 89(4): 463 - 471.

18. Bello-Flores, C.A., Nuñez-Santiago, M. C., Martín-Gonzalez, M. F., BeMiller, J. N. and Bello-Pérez, L. A. (2014). Preparation and characterization of octenylsuccinylated plantain starch. International Journal of Biological Macromolecules, 70: 334 - 339.

19. Karim, A. A., Nadiha, M. Z., Chen, F. K., Phuah, Y. P., Chui, Y. M. and Fazilah, A. (2008). Pasting and retrogradation properties of alkali-treated sago (Metroxylon sagu) starch. Food Hydrocolloids, 22(6): 1044 1053.

20. Wang, X., Li, X., Chen, L., Xie, F., Yu, L. and Li, B. (2011). Preparation and characterisation of octenyl succinate starch as a delivery carrier for bioactive food components. Food Chemistry, 126(3): $1218-1225$.

21. Hui, R., Qi-he, C., Ming-liang, F., Qiong, X. and Guo-qing, H. (2009). Preparation and properties of octenyl succinic anhydride modified potato starch. Food Chemistry, 114(1): 81 - 86.

22. Chi, H., Xu, K., Xue, D., Song, C., Zhang, W. and Wang, P. (2007). Synthesis of dodecenyl succinic anhydride (DDSA) corn starch. Food Research International, 40(2): 232 - 238.

23. Zhang, B., Huang, Q., Luo, F-X., Fu, X., Jiang, H. and Jane, J-1. (2011). Effects of octenylsuccinylation on the structure and properties of high-amylose maize starch. Carbohydrate Polymers, 84(4): 1276 -1281. 